\title{
Utilization of Digital Games in Built Environment Education
}

\author{
Burcu Gülay Taşçi \\ Department of Architecture, Faculty of Architecture, Dokuz Eylül University, Tınaztepe Campus, Turkey
}

Copyright $(\mathrm{C} 2016$ by authors, all rights reserved. Authors agree that this article remains permanently open access under the terms of the Creative Commons Attribution License 4.0 International License

\begin{abstract}
In this age, it is an accepted fact that architecture is not a phenomenon which comes into existence, only when it is constructed, but even the ideas which are at the stage of abstract thought, which have not been transformed into concrete buildings are also products of architecture. To this respect, it is possible to grind the rigid boundaries of architecture education and to bring new expansions to education. Many methods, as a support to the conventional ones, are used to equip the individuals, up to a level of necessities of the time, who have communed with technology since their birth. Digital game based learning is one of the innovative and inventive approaches. Utilization of learning via digital games in architecture and related fields may incur several reasons. As literature is reviewed, it is seen that different digital games were utilized for different reasons. Therefore it is thought that providing the mentioned reasons in a structured form is required for future studies. In this article prepared with this mindset, the aim is to "reveal which genre of digital games is used for which purposes regarding the fields associated with architecture". Screening method and document analysis were utilized in the research with the mentioned purpose. The research is limited to the digital games that are utilized in architecture and associated sub disciplines. The findings of the study reveal that the digital games are utilized with the purpose "to increase built environment awareness, to develop as a contributing citizen, to increase the design ability and to design in harmony with natural environment" mostly. Due to the current status of utilizing digital games in built environment education and revealing the shortcomings and the potential, it is thought that this article has significance and will provide a guideline for future studies.
\end{abstract}

Keyword Built Environment Education, Digital Game, Instructional Aims

\section{Introduction}

In 1980 's the personalization of the computers, which are indispensable tools of our age and being integrated in our daily lives resulted in drastic changes in which the methods of information processing and interpretation. Undoubtedly these changes influenced the education approaches and methods. As a result, the approach of learning via digital games which is utilized in the field of education via traditional tools is evolved to learning via digital game approach.

Learning via digital games is the realization of learning via instrumentalization of digital games that are education oriented or being utilized for the purpose of learning to enhance the quality and gains of the education experience. It is being mentioned that utilization of this approach in the field of education provides many advantages. For instance digital games have a great influence on developing literacy skills [1]. It is known that the individuals gain "image reading skills" [2,3] develop "mental rotation and spatial skills" [3], significantly improve the visual awareness [2,4]; develop problem solving skills $[3,5,6,7]$ by ensuring full motivation and contribution to teaching hard subjects and content $[3,8]$.

Due to the mentioned advantages, today the digital games are utilized in many schools of architecture. The aim to utilize the digital games is to develop designing skills in certain instances and improve upon the gains in theoretic lectures. In this article, the utilization of digital games in architecture and associated sub disciplines is handled, and the purpose and content of the applications in literature is investigated.

\section{The Definition of the Problem and the Aim}

The problem addressed in the article is the lack of a holistic study addressing the current status of utilization of digital games in built environment education. The aim is to fill this gap and by determining the digital games that are already utilized in built environment education, revealing the potential of digital games for future studies.

\section{Method}

In order to develop a holistic perspective, it is thought 
viable to complete a comprehensive literature screen including the internet and published resources. For this reason qualitative research method and document analysis are utilized in this study. The research is limited to the digital games that are utilized in architecture and associated sub disciplines.

In the study, the following questions are focused on in the literature review; i) In what context do game and architecture education enter into connection? (related with sub-disciplines and courses); ii) which game type would be used in what way?; and iii) what should the general properties of a game designed focusing on architecture be? The content of the study is presented in plain text format to answer these questions. Also the findings on "for what purposes the digital games could be used in architecture education" are summarized via a classification conducted by the researcher.

\section{Findings}

In the preliminary study conducted at the beginning of this study, it is seen that there is not any clear and conclusive classification for computer games in the literature. Everyone, including the gaming industry and the academicians use different taxonomies [3]. However, still it is possible to make some groupings with regard to the prominent features and the determining structures of the games. Simulation, role playing, strategy, action, adventure games are some of these categories [9].

Numerous games from various categories could be benefited in education related to architecture. However, to most frequently encountered and the most widely used games in architecture education are the simulation games. "The use of this game genre in the architecture studios as a means of problem solving dates back to the 1960's. The simulation games can be used in architecture education for numerous purposes such as planning and the preservation of the built-environment, pointing out historical resources, determining the holistic characteristics of a certain area, bringing inactive areas into use again, acoustic and thermal performance calculations etc. " [10].

There are many renowned simulation games. Simcity, a city administration and strategy game with the "community land use game" style, is one of the games used in architecture and planning. Hosny et al. investigated the effects of using simulation games in architecture over the Simcity example, and observed that Simcity could represent real life situations, included decision making tools, and was sufficient for conducting analysis, providing supervision to the gamer and allowing the gamer to self-evaluate the performance [11]. Marlow, too, had similar observations, defining Simcity as a serious and epistemic game [7].

When Simcity is discussed from a theoretical perspective, it can be argued that it is a game, based on the action-review-planning-action process, which dictates the constructivist learning approach appropriate for the experiential and empirical learning style. So Hosny et al. argue that digital games could be used in architecture education, basing on this game [11].

Another game frequently encountered in education is Sims, which is defined as a simulation game. Sims is used in many different disciplines. Based on a study by Gros, it is known that interior design is a significant area of interest in Sims, and especially female students use the game for decorative purposes [3]. Although a literature finding obtained from architecture schools could not be found, it can be asserted that this game could be used in interior design in architecture education. The experience provided by Sims for spatial design is theoretically based on learning by doing. As a result of working with 3D models in this game, it is possible to materialize the design in a short time and to evaluate this design in a user-centred manner.

Another game genre which enters into connection with architecture education is the role playing game category. Second Life can be given as an example to this category, where information is structured by playing roles aimed at some fictional purpose in a realistic or fantastic environment. The use of this game, which is defined as an online role playing game, in relation with architecture can be found frequently in the literature for example, in Anglia Ruskin University Department of Built Environment. According to Hockey et al., the reasons for this game to be used this frequently in architecture education are that it provides interactive experience; allows for playing certain roles in real life situations and encourages tandem learning and participation [12]. Also this game allows the individual to manipulate his own learning style and provides a safe learning environment independent of time and space and free from risks. Marlow, too, asserts that this game improves creativity and thus could be used in education [7].

Another game category that can be considered as related to architecture and built environment education is the strategy games. For instance, it is known that Civilization games have been integrated into various courses in order to provide a background for discussion sessions due to the urban and historical models and parameters they include [13]. In a similar fashion, Age of Empires [5]. and Caeser [3] are used in many countries to get informed about historical environment. The British Educational Communications and Technology Agency (BECTA) assert that games like Caeser II and Age of Empires beneficial for history education, since they provide information about real event and real places [3].

When it is considered that architecture education is not composed of only design education, but is a holistic area of education covering familiarizing historical environment, developing environment protection consciousness, history education and culture-oriented aims, the significance of these games can be understood more clearly. If developed countries are considered, for instance in the USA, it is seen that the cultural heritage consciousness is earned by children in their early ages and the studies on this topic had started in the 1940's [14]. This kind of education, which is composed of abstract concepts mostly, should be supported by visual 
learning methods to increase learning achievements [15]. From this perspective, it is thought that historical strategy games would contribute to architecture, as a vocational practice, and to the society as a whole, as citizenship education.

All the games mentioned up to this point are, in fact, commercial games which do not prioritize education. However, as it is seen, these games, too, can be used as instructional games. There are also games with education as their primary objective; the first one to come into mind considering architecture is the one based on design education.

The Virtual Block World game, developed in Adelaide University Department of Architecture, is one of the design-oriented instructional games used for form production and space planning. This game which is used as support to architecture education, adopts Froebel's design by wooden blocks methods, i.e. Dewey's [16] learning by doing approach. "In this game, which comprises of two stages, first spatial organization is performed using the virtual object blocks by taking reference some certain keywords; later volumetric organization is performed using the virtual 'space' blocks. In this game, where the process is important, not the resulting products, there are positive outcomes such as giving meaning to space, gaining spatial awareness, thinking with metaphors in favor of perceiving the main issues of design and thinking architecture as a dynamic experience" [17].

Another example to the games with education focused design can be provided with relation to the sustainability education. The games designed in relation with the sustainability education are mostly encountered in landscape architecture education. The aim of these games is generally to raise environment consciousness. It is known that digital games have been used in the studies on landscape architecture education, recently. For instance International Strategy for Disaster Reduction (ISDR) has developed a game, "Stop Disasters" to raise awareness about natural environments; and provides information to the students on ensuring the security of the cities during natural disasters [18]. The Navigating Nature game, mentioned by Marlow [7]; UWB Wetlands Restoration Game mentioned by Örnek [19] can also be considered in this respect which has been used to explain the importance of the ecosystem and ecology to the students. Apart from all these examples, it is known that there are many games among commercial games that can be used in sustainability education such as Green Space, Roller Coaster Tycoon 3, and these games are used in landscape architecture education in some schools. To summarize, it can be argued that computer games can also be used in architecture for landscaping education, and their uses are mostly, raising awareness about environmental sustainability and making designs.

\section{Results}

It is seen that the relation of digital game-based education to architecture could be made over both theoretical lessons and project studios. In architecture education, which the project is at the center and is supported by the theoretical courses, the contribution of game to the theoretical courses is directly reflected upon the project processes. Although, the said theoretical courses are called in different names in different schools and curriculums, titles such as historical environment, sustainable architecture, participation in architecture and management are frequent. The contributions of digital game use to certain courses and project processes encountered in the literature are summarized in Figure 1.

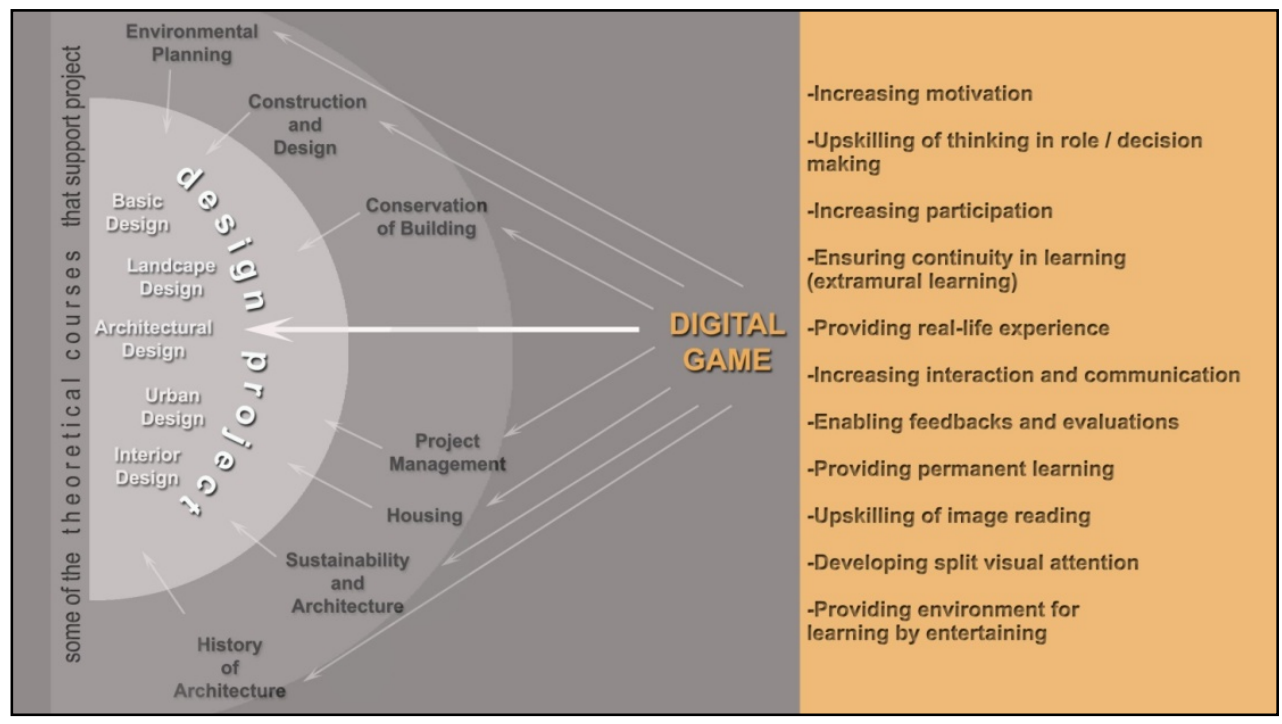

Figure 1. The use of digital games in architecture education (Source: Author, 2015). 
A great number of games has been examined in this study, but only the games that are encountered frequently in the literature and that can be related to architecture education are elaborated. When the information obtained from the literature review conducted in the study is considered the following rough conclusion has been drawn. Mostly historical strategy games are preferred in built environment, historical and cultural heritage education; simulation games are mainly used in design education; and the role playing games are preferred in contribution and collective task oriented education.
In addition to the instructional uses of the aforementioned commercial games, non-commercial games specially designed to be used in all the areas mentioned above are found also.

As it is mentioned before, it is not possible to determine all these game genres with clear cut boundaries. It is possible to relate them to architecture education from different aspects due to their structural properties and their predefined intended uses. The games mentioned in the literature on architecture education and their relation to the sub-disciplines of architecture is summarized in Table 1.

Table 1. Games mentioned in the literature and inferences about their uses (Source: Author, 2015).

\begin{tabular}{|c|c|c|c|c|c|c|c|}
\hline \multirow[b]{3}{*}{$\begin{array}{l}\text { List of games } \\
\text { utilized } \\
\text { associated } \\
\text { with } \\
\text { architecture } \\
\text { and related } \\
\text { fields in the } \\
\text { literature }\end{array}$} & \multicolumn{7}{|c|}{ Instructional use of game in architecture and related fields } \\
\hline & \multirow[b]{2}{*}{$\begin{array}{c}\text { Developing } \\
\text { aw areness } \\
\text { to conserve } \\
\text { history and } \\
\text { culture }\end{array}$} & \multirow[b]{2}{*}{$\begin{array}{c}\text { Teaching } \\
\text { environmental } \\
\text { sustainability }\end{array}$} & \multirow[b]{2}{*}{$\begin{array}{l}\text { Developing a } \\
\text { consciousness } \\
\text { to contribution } \\
\text { and collective } \\
\text { w orking }\end{array}$} & \multicolumn{4}{|c|}{ Design education } \\
\hline & & & &  & 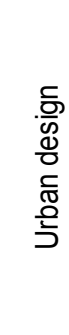 & 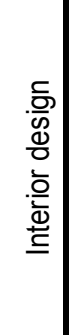 & 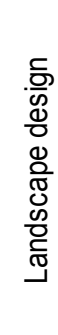 \\
\hline $\begin{array}{l}\text { Age of } \\
\text { Empires }\end{array}$ & $\mathbf{X}$ & & $\mathbf{x}$ & & $\mathbf{x}$ & & \\
\hline Caesar II & $\mathbf{x}$ & & & & $\mathbf{x}$ & & \\
\hline Civilization & $\mathbf{x}$ & & $\mathbf{x}$ & & $\mathbf{x}$ & & \\
\hline Eectro city & & $\mathbf{x}$ & $\mathbf{x}$ & & $\mathbf{x}$ & & $\mathbf{x}$ \\
\hline ETH game & & & $\mathbf{x}$ & $\mathbf{x}$ & & & \\
\hline Energy Ville & & $\mathbf{x}$ & & & $\mathbf{x}$ & & \\
\hline Green Space & & $\mathbf{x}$ & $\mathbf{x}$ & & & & $\mathbf{x}$ \\
\hline Half life & & & $\mathbf{x}$ & & & & \\
\hline $\begin{array}{l}\text { Navigating } \\
\text { nature }\end{array}$ & & $\mathbf{x}$ & & & & & $x$ \\
\hline Plant it green & & $x$ & $x$ & & $x$ & & $\mathbf{x}$ \\
\hline Restoration & & $\mathbf{x}$ & & & & & $x$ \\
\hline Revolution & $\mathbf{x}$ & & $\mathbf{x}$ & & & & \\
\hline RCT3 & & $x$ & & $x$ & $x$ & & $x$ \\
\hline Second life & $\mathbf{x}$ & & $\mathbf{x}$ & $\mathbf{x}$ & $\mathbf{x}$ & & $\mathbf{x}$ \\
\hline SimCity & & & $\mathbf{x}$ & & $\mathbf{x}$ & & \\
\hline Sims & & & & $x$ & & $x$ & \\
\hline Smart grids & & $x$ & $\mathbf{x}$ & & & & $x$ \\
\hline Stop Disasters & & $\mathbf{x}$ & & & & & $\mathbf{x}$ \\
\hline $\begin{array}{l}\text { UWB Wetlands } \\
\text { Restoration }\end{array}$ & & $x$ & $\mathbf{x}$ & & & & $\mathbf{x}$ \\
\hline
\end{tabular}




\section{Conclusion and Implications}

In conclusion, it can be said that computer games bring a dynamic approach to learning and can be used in architectural education. In order to elaborate this thought, it should be explained that why it is insufficient to continue architecture education, today, with only conventional approaches.

The architecture students at present were born into technology and received education with these opportunities since kindergarten. In the modern education approach, in which learning is student centered, it is essential that education should be organized with regard to the level and necessities of the student. The student's encounter with only drawing and model studies in higher education after their primary and secondary schools supported with visual media, creates a large gap between the students and the education system. Therefore, digital games, which are up-to-date and popular, should be used to adapt the student to education, to ensure their participation in the lessons, and to increase their motivation in the education processes.

Based on this conclusion, it is possible to pose a novel question. If computer games could be used for giving architecture at the professional level, what kind of a game should be this game?

As it is seen the literature review, different game genres can be used in architecture education. Therefore, what is important is not the genre of the game, but the features it should have.

One of the most important features of a game to be used in architecture education is that it should make the individual to have a real-life experience. Architecture education involves the design of difficult large scale buildings, cities, and it is impossible to encounter these situations in real life. The efficiency of a digital game in this respect can be acknowledged as one of the most determining factors for its use in architecture education.

In addition to this, a digital game to be used in architecture education should absolutely contain decision making tools and ensure conducting analyses. It should allow for self-evaluation of the gamer by providing supervision and guidance. Also, it is an important factor that the game must contain well-designed problems. The problem should be difficult but solvable, and should include strategies towards up skilling. It should provide the user with sufficient information and encourage him or her for cooperation [1].

In summary, a game designed especially for architecture should have the properties which a good game should have. Lastly, the question whether the solution is designing new games or interpreting the present games comes into mind. If it is to be answered basing upon the literature, it can be said that considering the commercial games in the market in educational terms is more favorable, since designing a new game is an onerous and expensive process [17]. However, it is known that there are some difficulties in manipulating a present game as intended, and organizing it pertinent to the curriculum in formal education. Therefore, developing an expansion pack for the game or designing operations integrated in the game via CAD based software could be the options. Similar interpretations from different perspectives may be possible. However, what is important is that these interpretations should have pedagogical background. As Marlow stated, in the process of revising a present game or designing a new game from scratch, the designer should have a good command of learning theories, like a good teacher [7]. In cases, where it is not possible to design a new game and the use of present commercial games with education purposes is at stake, the present games should definitely be reconsidered with regard to learning theories.

\section{REFERENCES}

[1] Gee, J.P. What video games have to teach us about learning and literacy? Pal Grave-McMillan, New York, 2003.

[2] Greenfield, P.M. Video games as cultural artefacts. In P.M. Green-field \& R.R. Cocking (Eds.), Interacting with video, NJ. Ablex Publishing, Norwood, 1996.

[3] Gros, B. Digital Games in Education: The Design of Games-Based Learning Environments, Journal of Research on Technology in Education Vol.40, No.1, 23-38, 2007.

[4] Green, C.S and Bavelier, D. Action Video Game Modifies Visual Selective Attention, Nature Vol. 423, No. 6939, 534-537, 2003.

[5] McFarlane, A., Sparrowhawk, A., and Heald, Y. Report on the Educational Use of Games, 2002. Online Available: https://pantherfile.uwm.edu/tjoosten/LTC/Gaming/teemgam esined_full.pdf, Access Date, 13/02/2014.

[6] Squire, K. Game-Based Learning: Present and Future State of the Field, University of Wisconsin-Madison Press, Madison, WI, 2005.

[7] Marlow, C.M. Games \& Learning in Landscape Architecture, 2009, Online Available: http://www.kolleg.loel.hsanhalt.de/landschaftsinformatik/fileadmin/user_upload/_tem p/2009/2009_Proceedings/605_marlow_games-2009-jun29e.pdf, Access Date, 04/02/2014.

[8] Ocak, M.A. Eğitsel Dijital Oyunların Eğitimde Kullanımı. In M.A.Ocak (Eds.), Eğitsel Dijital Oyunlar: Kuram, Tasarım ve Uygulama, Pegem Akademi, Ankara, 2013.

[9] Gelibolu, M. F. Eğitsel Dijital Oyunların Teknolojisi, Türleri, Sinıflandırılması, Derecelendirilmesi ve Eğitimde Kullanılabilme Potansiyeli. In M.A.Ocak (Eds.), Eğitsel Dijital Oyunlar: Kuram, Tasarım ve Uygulama, Pegem Akademi, Ankara, 2013.

[10] Onur, Z. Mimarlık Eğitiminde Simülasyon Oyunları, Mimarlık Vol. 264, No.19, 19, 1995.

[11] Hosny, S. S; Mohsen, A.M.A and Mahmoud, A.T.S. Games in Architectural E-ducation, 1990, Online Available: http://www.cpasegypt.com/pdf/Tamer_Samir_Mahmoud/Pa pers $/ 002 \% 20 \% 20 \% 20$ Games $\% 20$ in $\% 20$ Architectural $\% 20$ Education.pdf, Access Date, 27/09/2014. 
[12] Hockey, A. Esmail, F., Jimenez-Bescos, C., Freer, P. Built Environment Education in the Era of Virtual Learning, Special Track 18th CIB World Building Congress Salford, United Kingdom, 2010, Online Available:

http://www.irbnet.de/daten/iconda/CIB_DC24207.pdf, Access Date, 12/05/2013.

[13] Squire, K. and Barab, S. Replaying History: Engaging Urban Underserved Students in Learning World History through Computer Simulation Games, 6th International Conference on Learning Sciences, International Society of the Learning Sciences 505-512, 2004.

[14] Hunter, K. Heritage Education in the Social Studies, 1988, http://www.cool.conservation-us.org/bytopic/misc/heritedu.h tml, Access Date, 23/04/2012.

[15] Gülay Taşçı, B. Analysing the Children-Architecture Studies and a Built Environment Education Programme for Primary Schools (For Social Studies Curriculum), Dissertation, Dokuz Eylül University, Natural and Applied Sciences Institute, İzmir, 2014.

[16] Dewey, J. Experience and Education, Touchstone, New York, 1997.

[17] Çatak, G. Oynarken tasarlamak: Dijital Tasarım Oyunları. Sigma Vol. 3, 385-391, 2011.

[18] ISDR Online Video Game. Stop Disasters Game Website, 2007 Online Available: http://www.unisdr.org/2007/ campaign/online-game-en.htm, Access Date, 22/02/2014.

[19] Örnek, M.A. Exploring the potential uses of computer games in landscape architecture education, Itu A $\mid \mathrm{Z}$ Vol. 10 No. 2, 161-177, 2013, Online Available: http://www.az.itu.edu.tr/az vol10no2web/14-Ornek-1002.pdf, Access Date, 21/01/2014. 